\title{
Chemical Analysis and Antioxidant and Antimicrobial Activity of Essential oils from Artemisia negrei L. against Drug- Resistant Microbes
}

\author{
Khalid Chebbac, ${ }^{1}$ Abdelfattah EL Moussaoui, ${ }^{2}$ Mohammed Bourhia $\mathbb{D}^{3}{ }^{3}$ \\ Ahmad Mohammad Salamatullah $\mathbb{D}^{1},{ }^{4}$ Abdulhakeem Alzahrani, ${ }^{4}$ and Raja Guemmouh ${ }^{1}$ \\ ${ }^{1}$ Laboratory of Biotechnology Conservation and Valorisation of Natural Resources, Faculty of Sciences Dhar ElMahraz, \\ Sidi Mohammed Ben Abdallah University, Fez, Morocco \\ ${ }^{2}$ Laboratory of Biotechnology, Environment, Agri-food, and Health, University of Sidi Mohamed Ben Abdellah, \\ Faculty of Sciences Dhar ElMahraz, Fez, Morocco \\ ${ }^{3}$ Laboratory of Chemistry-Biochemistry, Environment, Nutrition, and Health, Faculty of Medicine and Pharmacy, \\ Hassan II University, Casablanca, B.P 5696, Casablanca, Morocco \\ ${ }^{4}$ Department of Food Science \& Nutrition, College of Food and Agricultural Sciences, King Saud University, P.O. Box 2460, \\ Riyadh 11451, Saudi Arabia
}

Correspondence should be addressed to Mohammed Bourhia; bourhiamohammed@gmail.com

Received 31 May 2021; Revised 7 August 2021; Accepted 17 August 2021; Published 8 September 2021

Academic Editor: Sebastião Silva

Copyright (c) 2021 Khalid Chebbac et al. This is an open access article distributed under the Creative Commons Attribution License, which permits unrestricted use, distribution, and reproduction in any medium, provided the original work is properly cited.

\begin{abstract}
Background. Artemisia negrei L. (A. negrei) is a medicinal and aromatic plant belonging to the family Asteraceae that is more widespread in the folded Middle Atlas Mountains, Morocco. Materials and Methods. This study was run to investigate the phytochemical composition and antioxidant, antibacterial, and antifungal activities of Artemisia negrei L. essential oil. This oil was extracted from the fresh plant material by using the Clevenger apparatus. The phytochemical composition was characterized by GC-MS. The antioxidant activity was evaluated using different methods including DPPH, $\beta$-carotene bleaching, and total antioxidant capacity. The antibacterial activity was tested vs. multidrug-resistant bacteria including both Gram-negative and Grampositive using inhibition zones in agar media and minimum inhibitory concentration (MIC) bioassays. The antifungal activity was conducted on Candida albicans, Aspergillus niger, Aspergillus flavus, and Fusarium oxysporum using a solid medium assay. Results. The chromatographic characterization of essential oils of $A$. negrei revealed the presence of 34 compounds constituting $99.91 \%$ of the total essential oil. The latter was found to have promising antioxidant activity by all bioassays used such as DPPH, $\beta$-carotene bleaching, and total antioxidant capacity. The results obtained showed that our plant oils had potent antibacterial activity towards Gram-negative (E. coli 57, E. coli 97, K. pneumonia, and P. aeruginosa) and Gram-positive (S. aureus), so that the maximum inhibition zones and MIC values were around $18-37 \mathrm{~mm}$ and 3.25 to $12.5 \mathrm{mg} / \mathrm{mL}$, respectively. The oil also showed antifungal activity towards Candida albicans, Fusarium oxysporum, and Aspergillus Niger except for flavus species. Conclusion. The findings obtained in the work showed that $A$. negrei can serve as a valuable source of natural compounds that can be used as a new weapon to fight radical damage and resistant microbes.
\end{abstract}

\section{Introduction}

Herbal medicine has become a more popular way of fighting against diseases and producing pharmaceutical medicines [1-3]. The use of herbal medicine for seeking potentially active compounds has been proven to promote scientific output [4]. Many synthesized drugs have come from natural sources including medicinal plants which can be available in the form of food supplements, nutraceuticals, and alternative and complementary medicines [5]. Plants are an 
important source of natural substances with great antioxidant potential [6]. Modern medicines place in priority the development of effective antioxidant substances from a natural source for being applied in the medical field for medication purposes [7]. Natural antioxidant agents received full consideration in the food industry to prevent oxidative deterioration of food by free radicals. These agents have been placed in priority for being used as an alternative to synthetic antioxidant agents such as butylated hydroxyanisole (BHA), butylated hydroxytoluene (BHT), and tertbutylhydroquinone (TBHQ) that are suspected of having serious side effects including carcinogenic and toxic effects [8].

Species among the genus Artemisia are used in traditional medicines for therapeutic purposes as antispasmodic, antirheumatic, antiinflammatory, antimicrobial, antihelminthics, and antiveinous agents $[9,10]$. Artemisia negrei L. is a medicinal plant endemic to Morocco lands, which is distributed in the region of the Moulouya Basin, and the folded Middle Atlas Mountains of Morocco. This plant is commonly used in Moroccan traditional medicines in treating diseases including digestive genital tracts and dermatological infections by using powder and infusion forms [9-11].

Antimicrobial resistance is a phenomenon where microbes evolve strategies to fight against drugs planned to attack them, so that the germs, which are not defeated, continue to develop powerfully as never before [7]. A few years ago, antimicrobial resistance has become one of the biggest problems that overburden the health care system and is classified as among the greatest challenge by the World Health Organization for 2019 [12].

In this study, the studied bacterial strains belong to drugresistant microbes such as $P$. aeruginosa, K. pneumonia, $S$. aureus, and E. coli pathogens. It is well known that these species can be multidrug-resistant [13]. Some of the fungal species studied in this work belong to drug-resistant microbes such as Candia spp., which was involved in the infection of more than $90 \%$ of people with AIDS in an earlier time. Candia spp. has developed unprecedented resistance due to excessive use of synthesized drugs to fight fungal infections caused by these microbes and continues to be a greatest growing health burden [14].

The current research study aimed to investigate the phytochemical composition and antioxidant, antifungal, antibacterial, and antifungal activities of $A$. negrei essential oil since no other studies have attempted this objective up to the time of writing this article.

\section{Materials and Methods}

2.1. Selection and Identification of Plant Material. A. negrei was harvested in June 2019 from the Middle Folded Atlas, Morocco $(2100 \mathrm{~m}, 33.539648,-3.894474)$. The authentification was done by a botanist with reference \# BPRN/04/18 that was deposited at the herbarium of Sidi Mohammed Ben Abdallah University, Fez, Morocco. Next, aerial parts of $A$. negrei were subjected to dry in a ventilated place for 10 days before extraction.
2.2. Extraction of Essential Oil. In the present work, the oil was extracted from the fresh plant material by using the Clevenger apparatus. In brief, a total of $200 \mathrm{~g}$ of aerial parts (leaves) were cut into small pieces before being placed into a flask with $750 \mathrm{~mL}$ of distilled water. Afterward, the whole solution was boiled for $3 \mathrm{~h}$ to maximize the essential oil extraction. The essential oil yield was obtained by using the following formula:

$$
\mathrm{RHE}=\frac{M^{\prime}}{M} \times 100,
$$

where RHE is essential oil yield in \%; $M^{\prime}$ ' is essential oil mass recovered in grams; $M$ is plant material mass in grams.

2.2.1. Analysis of the Phytochemical Composition of the Oil. The phytochemical characterization of essential oil was effectuated by GC-MS using a nonpolar silica column. To fulfill this goal, the operating conditions of the analysis were run as follows: the initial temperature was set to $40^{\circ} \mathrm{C} / 2 \mathrm{~min}$ along with speed $2^{\circ} \mathrm{C} / \mathrm{min}$, while the final and injector temperatures were set to $260^{\circ} \mathrm{C} / 10 \mathrm{~min}$ and $250^{\circ} \mathrm{C}$, respectively. In this analysis, helium gas was used as a vehicle $(1 \mathrm{~mL} / \mathrm{min})$ with "split" mode injection. The ionization energy and ion source temperature were $70 \mathrm{eV}$ and $200^{\circ} \mathrm{C}$, respectively, and the scan mass range $\mathrm{m} / \mathrm{z}$ is $40-650$. The oil was diluted in hexane solvent $(10: 100)$ before being injected with $1 \mu \mathrm{L}$. The chemical identification was done by using retention indices (RI) along with comparison with ADAMS database [15].

2.3. Antioxidant Activity. In this study, the antioxidant power of the oil from $A$. negrei was evaluated using three bioassays including DPPH, $\beta$-carotene bleaching, and total antioxidant capacity [16].

\subsubsection{DPPH Radical Scavenging Activity. DPPH bioassay} was carried out using protocols as reported by Tepe et al. [17]. Both the essential oil (EO) and the positive control (BHT) were used at different concentrations including $1,1 /$ $4,1 / 8,1 / 16,1 / 32,1 / 64,1 / 128,1 / 256$, and $1 / 512 \mathrm{mg} / \mathrm{mL}$. The anti-free radical activity was evaluated by mixing $100 \mu \mathrm{L}$ of each previously prepared concentration (EO and $\mathrm{BHT}$ ) with $750 \mu \mathrm{L}$ of DPPH $(0.004 \%)$. Afterward, the solution was incubated at ambient temperature for 30 minutes before reading the absorbance. The DPPH scavenging ability was expressed as inhibition percentage as follows:

$$
\operatorname{PI}(\%)=(A 0-A / A 0) * 100,
$$

where $\mathrm{PI}$ is the percentage of inhibition, $A 0$ is the absorbance of DPPH without the sample (control), and $A$ the absorbance of DPPH with the sample.

2.3.2. Total Antioxidant Capacity Test (TAC). The TAC test was carried out according to the protocol reported in the earlier work [18]. In brief, $25 \mu \mathrm{L}$ of the sample test $(1 \mathrm{mg} / \mathrm{mL})$ was mixed with one milliliter of reagent solution constituted 
of sodium phosphate, sulphuric acid, and ammonium molybdate. Next, the whole solution was placed for incubation at $95^{\circ} \mathrm{C}$ for 90 min before measuring the absorbance at $695 \mathrm{~nm}$ using a spectrophotometer [18]. BHT and Quercetin were used as standard references. The TAC has expressed in $\mathrm{mg} \mathrm{EAA} / \mathrm{g} \mathrm{HE}$.

2.4. $\beta$-Carotene Bleaching Assay. This assay was performed to study the antioxidant power of essential oil from $A$. negrei using the protocol as reported in the literature $[19,20]$. In brief, $1 \mathrm{~mL}$ of $\beta$-carotene chloroform solution was added to $10 \mu \mathrm{L}$ of solution constituted of linoleic acid and $100 \mathrm{mg}$ of Tween 80. Next, the chloroform was retrieved using a vacuum rotary evaporator before adding $25 \mathrm{~mL}$ of hydrogen peroxide to the residue. Afterward, $2.5 \mathrm{~mL}$ of the obtained mixture was added to $100 \mu \mathrm{L}$ of the sample test $(1 \mathrm{mg} / \mathrm{mL})$ and then maintained in the water bath at $51^{\circ} \mathrm{C}$ for $2 \mathrm{~h}$. BHT was used as a standard reference $(1 \mathrm{mg} / \mathrm{mL})$. The absorbance was measured at $470 \mathrm{~nm}$. The antioxidant power was calculated as a percentage of antioxidant activity relative to the control as follows:

$$
\mathrm{AA} \%=(\mathrm{AE} / \mathrm{ABHT}) * 100 .
$$

$\mathrm{AA} \%$ is the antioxidant property percentage, and ABHT is the absorbance of the positive control, while $\mathrm{AE}$ is the absorbance of the negative control.

2.5. Antibacterial Activity. The evaluation of the antimicrobial activity of the essential oils was carried out according to the previously reported data elsewhere [16]. The essential oil of $A$. negrei was tested vs. Gram-negative bacteria Pseudomonas aeruginosa, Escherichia coli ATB:57; Klebsiella pneumoniae, and Escherichia coli ATB:97 and Gram-positive bacteria (Staphylococcus aureus (LM, FMP, and Fez)). The strains tested in the current study were clinically isolated and have been reported as multidrug-resistant as reported in earlier work $[13,21,22]$. The bacterial suspension was prepared from fresh culture. To achieve this goal, few colonies from the culture were aseptically seeded in $0.9 \%$ of physiological water at a density of $0.5 \mathrm{McFarland}$, which corresponded to $10^{7}$ to $10^{8} \mathrm{CFU} / \mathrm{mL}$ [23].

The antibacterial activity was studied using the disc diffusion method. In brief, a volume of $10 \mu \mathrm{L}$ of $A$. negrei essential oil $(1 \mathrm{mg} / \mathrm{mL})$ was used for testing purposes, while ampicillin $1.68 \mathrm{mg} /$ disc and streptomycin $0.020 \mathrm{mg} /$ disc were used as drug references as reported in earlier work [20].

The minimum inhibitory concentrations (MICs) were studied by using the microdilution assay [24]. In brief, MIC was assessed by using the microdilution method in 96 -well plates. The concentrations of the oil were prepared in a $0.2 \%$ agar suspension. The concentrations were obtained by successive dilutions ( 25 to $0.02 \mathrm{mg} / \mathrm{mL}$ ). Finally, the plates were placed for incubation at $37 \mathrm{C}$ for $18 \mathrm{~h}$. Next, the bacterial growth was visualized after adding $20 \mu \mathrm{L}$ of triphenyltetrazolium in $5 \mathrm{mg} / \mathrm{mL}$ wells before further incubation for $30 \mathrm{~min}$ at $37^{\circ} \mathrm{C}$ [23].
2.6. Antifungal Activity of Essential Oils from Artemisia negrei. The antifungal activity of the studied oil was conducted using four fungal species including Candida albicans ATCC 10231, Aspergillus niger (LBEAH/FS/19), Aspergillus flavus (LBEAH/FS/18), and Fusarium oxysporum (LBEAH/FS/17). The disk diffusion method was used to achieve this goal as described elsewhere [25]. In brief, Petri dishes with MEA medium were inoculated with C. albicans, A. niger, A. flavus, and $F$. oxysporum. Next, Whatman paper disks $(6 \mathrm{~mm}$ in diameter) impregnated with $10 \mu \mathrm{L}$ of essential oils were placed on the surface of Petri dishes before being incubated at $30^{\circ} \mathrm{C}$ in the darkness. The inhibition diameter, as well as inhibition percentage, was determined after $48 \mathrm{~h}$ of incubation for C. albicans and after 7 days for A. niger, A. flavus, and F. oxysporum [26, 27].

2.7. Statistical Analysis. The obtained results were expressed as means \pm SEM of triplicate assays. Statistical analysis was conducted using the ANOVA test. A significant difference was statistically considered when $p<0.05$.

\section{Results and Discussion}

3.1. Phytochemical Compounds of Essential Oil. The obtained results showed that the yield of essential oil of $A$. negrei was $1.2 \%$. The highest percentage of essential oil of the genus Artemisia was recorded for Artemisia cana (1.3\%) and Artemisia frigida (1.5\%). However, the essential oil yield of the aerial part of Artemisia absinthium, Artemisia biennis, Artemisia dracunculus, and Artemisia ludoviciana ranges from $0.3 \%$ to $0.5 \%$, which is lower than that of $A$. negrei [28]. This yield can be considered important in comparison with some plants that are industrially exploited as a source of essential oils such as rose $(0.1-0.35 \%)$, rosemary $(1-2.5 \%)$, peppermint $(0.5-1 \%)$, neroli $(0.5-1 \%)$, lavender $(0.8-2.8 \%)$, aniseed (1-3\%), and thyme (2-2.75\%) [29].

The chromatographic analysis of essential oil of A. negrei from the folded Middle Atlas revealed the presence of 34 volatile constituting $99.91 \%$ of the total essential oil recovered from fresh material (Figure 1; Table 1). The chemical analysis showed that the characterized essential oil possessed many potentially bioactive substances including thujone (29.02\%), 2-bornanone (14.68\%), octacosane (14.02\%) eucalyptol (5.60\%), endoborneol (3.78\%), bicyclo (3.1.0) hexan-3-on (3.63\%), pentacosane $(3.07 \%)$, and camphene $(2.38 \%)$. Some compounds identified in the current oil ( $\beta$-thujone, $\alpha$-thujone, borneol, camphor, and 1.8-cineol) were also identified in closer plant species including Artemisia herba-alba L., Artemisia pontica L., Artemisia absinthium L. [25-27]. Thujone as a major element in the studied oil has been largely identified in essential oils of plants that are used for food and/or medicinal purposes [30].

3.2. DPPH Free Radical Scavenging Activity. The results obtained showed that the studied oil exhibited a potent $\mathrm{DPPH}$ free radical scavenging activity $(\mathrm{IC} 50=0.0164 \pm$ $0.0011 \mathrm{mg} / \mathrm{mL})$ when compared to BHT $(0.0082 \pm 0.002 \mathrm{mg} /$ $\mathrm{mL}$ ) (Figure 2). Our oil with $\mathrm{IC}_{50}=0.0164 \pm 0.0011 \mathrm{mg} / \mathrm{ml}$ is 


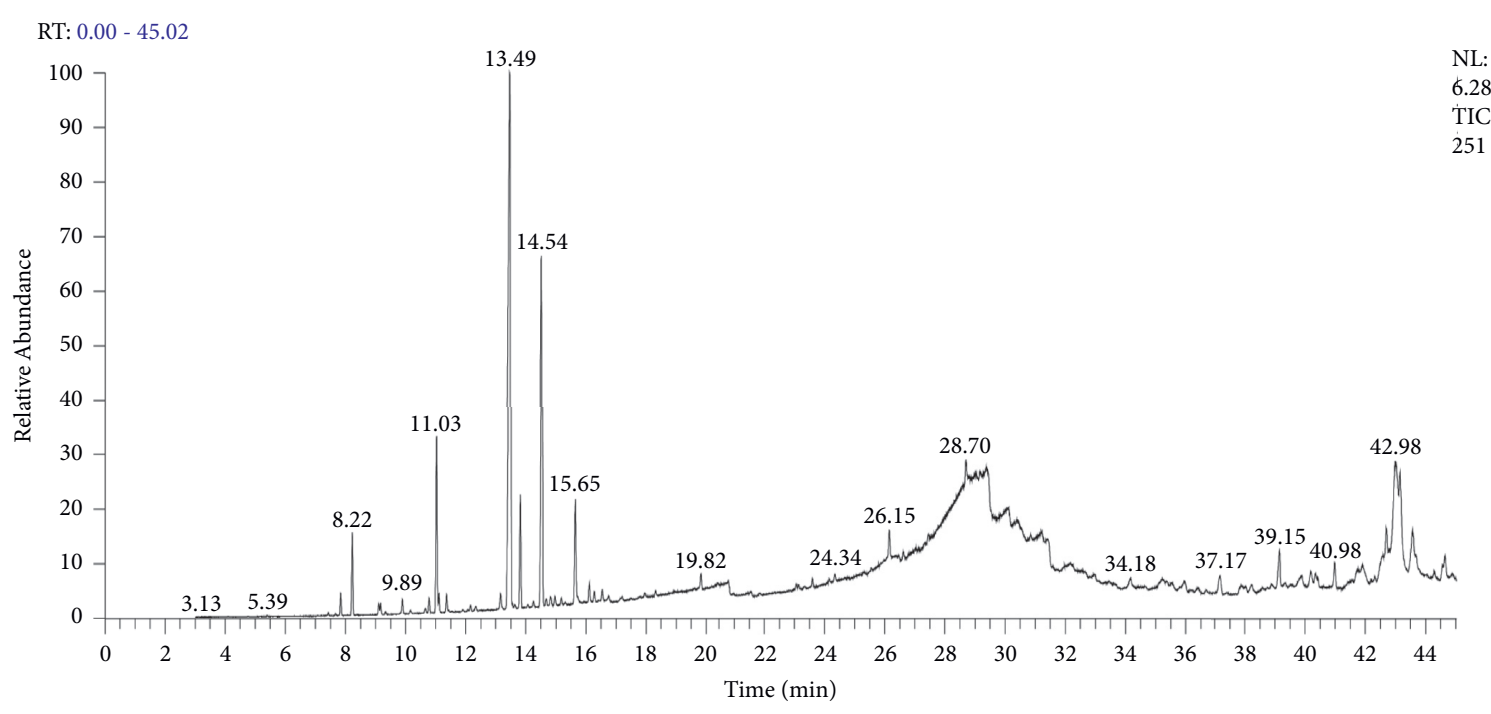

FIgURE 1: GC-MS chromatographic profile of essential oil from A. negrei.

relatively better than that found for oil extracted from $\mathrm{Ar}$ temisia dranculus growing in Turkey, which showed $\mathrm{IC}_{50}=100.200,400$, and $1000 \mu \mathrm{g} / \mathrm{ml}$ [31], and Artemisia herba alba from southwest Tunisia $\left(\mathrm{IC}_{50}=50.00 \mu \mathrm{g} / \mathrm{mL}\right)$ [32]. As shown in Table 1, A. negrei essential oil contains a higher amount of oxygenated monoterpenes, so that it can be a promising source of radical scavenging agents [33].

3.3. Total Antioxidant Capacity. In the current research work, the obtained findings showed that the essential oil from $A$. negrei had promising total antioxidant capacity with a value of $867.71 \pm 30.21 \mathrm{mg} / \mathrm{g}$ when compared to $472.29 \pm 6.19 \mathrm{mg} / \mathrm{g}$ of BHT and $307.65 \pm 13.08 \mathrm{mg} / \mathrm{g}$ of quercetin. It has been indicated that the antioxidant activity of essential oils is closely related to compounds with hydroxyl functions such as alcohols, and phenolic compounds $[30,31]$.

3.4. $\beta$-Carotene Discoloration Test. The evaluation of the antioxidant activity of the extract by using different assays is largely appreciated for comparison purposes [34]. It is thus fitting that the $\beta$-carotene bleaching method was used to achieve this goal. A follow-up of the $\beta$-carotene oxidation reaction in the presence of the oil and the standard reference (BHT) was performed by measuring the intensity of $\beta$ carotene color at a wavelength of $470 \mathrm{~nm}$. As shown in Figure 3, the results reported in percentages indicate that A. negrei oil exhibited potent inhibitory capacity $(74.1428 \%)$ when compared to BHT (100\%). The test used showed that A. negrei oil was a good hydrogen donor so that it is capable of being a free radical scavenger to control oxidation [35].

The investigated results in this work showed that A. negrei exhibited strong antioxidant power that may result from thujone as a major compound detected in the studied oil by GC-MS analysis [36]. In this sense, thujone ( $\alpha$ and $\beta$ ) has been reported to have anti-free radical activity as reported elsewhere [37]. The findings obtained in this work are consistent with those reported elsewhere [38], which demonstrated that essential oil from genus Artemisia revealed antioxidant activity of DPPH and ABTS assays. Many works have investigated the relationship between the phytochemical content of the essential oil and the antioxidant potential. In this sense, it was reported that antioxidant power is closely related to the presence of chemicals with hydroxyl function [39]. Therefore, the oil higher in phenolic compounds along with terpene alcohols can have a strong antioxidant effect [40]. According to the results obtained, the essential oils of Artemisia species showed a very high antioxidant efficacy even at the lowest concentration tested, so that we can confirm that this potent activity is explained by the richness of the oil in oxygenated monoterpenes.

3.5. Antibacterial Activity of Essential Oils of Artemisia negrei. Faced with the problems of antimicrobial resistance to synthetic antibiotics, much work has been conducted on the antimicrobial power of natural products including essential oils of certain plants. In this research study, the antimicrobial power of $A$. negrei essential oil was tested vs. five strains including E. coli 57, E. coli 97, K. pneumoniae, $P$. aeruginosa, and $S$. aureus as multidrug-resistant bacteria with a high frequency of contamination and pathogenicity [22]. In this study, the antibacterial activity was evaluated by using inhibition zone diameter (Table 2) and MIC bioassays (Table 3). The results obtained showed that our plant oil had potent antibacterial activity towards E. coli 57, E. coli 97, $K$. pneumoniae, $P$. aeruginosa, and $S$. aureus since the maximum inhibition zones and MIC values were around $18-37 \mathrm{~mm}$ and $1.56-12.5 \mathrm{mg} / \mathrm{mL}$, respectively, towards these species (Figure 4). $1.56 \mu \mathrm{g} / \mathrm{mL}$ was sufficient to inhibit the growth of $P$. aeruginosa (Gram negative), which was the most sensitive to the studied oil followed by E. coli 9, E. coli 57 , and K. pneumonia (Gram negative), which were completely inhibited by $6.25 \mu \mathrm{g} / \mathrm{mL}$. On the other hand, S. aureus $(\mathrm{Gram}+)$ was seriously inhibited at a concentration of $12.5 \mu \mathrm{g} / \mathrm{mL}$. All strains were found to be resistant to the 
Table 1: Phytochemical components identified in A. negrei essential oil by GC-MS.

\begin{tabular}{|c|c|c|c|c|c|c|}
\hline \multirow{2}{*}{ Peak } & \multirow{2}{*}{$\mathrm{RT}(\min )$} & \multirow{2}{*}{ Compound Name } & \multicolumn{2}{|c|}{ RI } & \multirow{2}{*}{ Molecular Formula } & \multirow{2}{*}{ Area (\%) } \\
\hline & & & Obs & Lit & & \\
\hline 1 & 7.84 & $\alpha$-Pinene & 938 & 939 & $\mathrm{C} 10 \mathrm{H} 16$ & 0.61 \\
\hline 2 & 8.22 & Camphene & 965 & 959 & $\mathrm{C} 10 \mathrm{H} 16$ & 2.38 \\
\hline 3 & 9.17 & $\beta$-Pinene & 976 & 979 & $\mathrm{C} 10 \mathrm{H} 16$ & 0.29 \\
\hline 4 & 9.89 & Myrcene & 988 & 990 & $\mathrm{C} 10 \mathrm{H} 16$ & 0.37 \\
\hline 5 & 10.78 & Cymene & 1024 & 1024 & $\mathrm{C} 10 \mathrm{H} 14$ & 0.44 \\
\hline 6 & 11.03 & Cineole & 1031 & 1031 & $\mathrm{C} 10 \mathrm{H} 18 \mathrm{O}$ & 5.60 \\
\hline 7 & 11.11 & Limonene & 1029 & 1029 & $\mathrm{C} 10 \mathrm{H} 16$ & 0.50 \\
\hline 8 & 11.36 & Fenchone & 1086 & 1086 & $\mathrm{C} 10 \mathrm{H} 18 \mathrm{O}$ & 0.50 \\
\hline 9 & 13.16 & Artemisia alcohol & 1073 & 1083 & $\mathrm{C} 10 \mathrm{H} 18 \mathrm{O}$ & 0.50 \\
\hline 10 & 13.49 & $\beta$-Thujone & 1111 & 1114 & $\mathrm{C} 10 \mathrm{H} 16 \mathrm{O}$ & 29.02 \\
\hline 11 & 13.82 & $\alpha$-Thujone & 1100 & 1102 & $\mathrm{C} 10 \mathrm{H} 16 \mathrm{O}$ & 3.63 \\
\hline 12 & 14.54 & Camphenol & 1110 & 1113 & $\mathrm{C} 10 \mathrm{H} 16 \mathrm{O}$ & 14.68 \\
\hline 13 & 15.65 & Borneol & 1169 & 1169 & $\mathrm{C} 10 \mathrm{H} 18 \mathrm{O}$ & 3.85 \\
\hline 14 & 16.11 & Limonen-4-ol & 1662 & 1667 & $\mathrm{C} 10 \mathrm{H} 18 \mathrm{O}$ & 0.56 \\
\hline 15 & 16.54 & $\alpha$-Terpineol & 1132 & 1133 & $\mathrm{C} 10 \mathrm{H} 18 \mathrm{O}$ & 0.35 \\
\hline 16 & 19.85 & Bornyl acetate & 1286 & 1288 & $\mathrm{C} 12 \mathrm{H} 20 \mathrm{O} 2$ & 0.51 \\
\hline 17 & 20.81 & Geranyl formate & 1291 & 1298 & $\mathrm{C} 11 \mathrm{H} 18 \mathrm{O} 2$ & 0.88 \\
\hline 18 & 26.15 & $\alpha$-Copaene & 1376 & 1376 & C15H24 & 1.00 \\
\hline 19 & 28.70 & Aromadendrene epoxide & 1641 & 1641 & $\mathrm{C} 15 \mathrm{H} 24 \mathrm{O}$ & 1.20 \\
\hline 20 & 29.43 & Cycloisolongifol-5-ol & 1510 & 1513 & $\mathrm{C} 15 \mathrm{H} 26 \mathrm{O}$ & 2.88 \\
\hline 21 & 30.12 & $\alpha$-Acoreno & 1630 & 1633 & $\mathrm{C} 15 \mathrm{H} 26 \mathrm{O}$ & 1.30 \\
\hline 22 & 31.44 & $\gamma$-Muurolene & 1476 & 1479 & $\mathrm{C} 15 \mathrm{H} 24$ & 1.17 \\
\hline 23 & 37.17 & Curcuphenol & 1716 & 1718 & $\mathrm{C} 15 \mathrm{H} 22 \mathrm{O}$ & 1.09 \\
\hline 24 & 39.15 & Hexadecanoic acid & 1957 & 1960 & $\mathrm{C} 16 \mathrm{H} 32 \mathrm{O} 2$ & 1.72 \\
\hline 25 & 40.19 & Coumarin & 1793 & 1434 & $\mathrm{C} 17 \mathrm{H} 28 \mathrm{O} 2$ & 0.65 \\
\hline 26 & 40.99 & Trihydroxy benzaIdehyde & 1818 & 1819 & C7H6O4 & 1.05 \\
\hline 27 & 41.77 & Isopropyltetradecanoate & 1823 & 1829 & $\mathrm{C} 17 \mathrm{H} 34 \mathrm{O} 2$ & 0.56 \\
\hline 28 & 41.91 & Isotorquatone & 1884 & 1845 & $\mathrm{C} 15 \mathrm{H} 22 \mathrm{O} 4$ & 1.43 \\
\hline 29 & 42.56 & Lanceol acetate & 1854 & 1855 & $\mathrm{C} 17 \mathrm{H} 2602$ & 0.95 \\
\hline 30 & 42.69 & Thujopsenic acid & 1863 & 1864 & CI5H2202 & 1.54 \\
\hline 31 & 43.02 & Octacosane & 2798 & 2800 & C28H58 & 14.02 \\
\hline 32 & 43.57 & Pentacosane & 2497 & 2500 & C25H52 & 3.07 \\
\hline 33 & 44.56 & Octadecanoic acid, ethylester & 2122 & 2125 & $\mathrm{C} 20 \mathrm{H} 40 \mathrm{O} 2$ & 0.60 \\
\hline 34 & 44.64 & Hexadecanol & 1874 & 1875 & CI6H34O & 1.01 \\
\hline \multicolumn{6}{|c|}{ Total identified } & $99.91 \%$ \\
\hline \multicolumn{6}{|c|}{ Monoterpene hydrocarbons } & $4.59 \%$ \\
\hline \multicolumn{6}{|c|}{ Oxygenated monoterpenes } & $58.69 \%$ \\
\hline \multicolumn{6}{|c|}{ Sesquiterpene hydrocarbons } & $2.17 \%$ \\
\hline \multicolumn{6}{|c|}{ Oxygenated sesquiterpenes } & $9.44 \%$ \\
\hline \multicolumn{6}{|c|}{ Others } & $25.02 \%$ \\
\hline
\end{tabular}

RT: retention time (min); RI: retention indices; Obs: calculated retention indices of phytochemicals found in A. negrei essential oils; Lit: retention indices of phytochemicals found in the literature.

tested antibiotics except for S. aureus (Gram+), which was found to be highly sensitive to Streptomycin with an inhibition zone diameter of $9.32 \pm 0.84 \mathrm{~mm}$ and resistant to ampicillin. The antibacterial effect of the oil from A. negrei can be explained by the presence of oxygenated monoterpenes identified in oil particularly thujone, eucalyptol, endoborneol, 2-bornanone, and $\beta$-terpineol reported to possess interesting pharmacological activities [41]. These findings were proven by Kordali [31], who showed that the oils of closer species such as Artemisia santonicum and Artemisia spicigera possessing a high level of bioactive oxygenated monoterpenes. On the other hand, a wormwood A. campestris, which is mainly composed of hydrocarbon monoterpenes, revealed a weak antimicrobial activity against pathogenic germs such as E. coli and S. aureus [42]. For getting the antimicrobial effect, antibiotics need to reach and interact with specific target sites. However, the antimicrobial agent is frequently interrupted due to the intervention of different mechanisms in bacteria, which lead to the failure of antimicrobial agents, so that bacteria continue to develop strongly [43]. The low sensitivity of Gram-negative bacteria to antibiotics may result in an outer membrane covering the cell wall, which interacts with the diffusion of hydrophobic agents through the lipopolysaccharide coating. Essential oil from natural sources can successfully cross the cell walls of bacteria and the cytoplasmic membrane inducing disorders of macromolecules (fatty acids, polysaccharides, and phospholipids) [44]. In this work, essential oil from A. negrei has almost closer activity vs. Gram-positive as much as Gram-negative bacteria. Hence, we could confirm that 


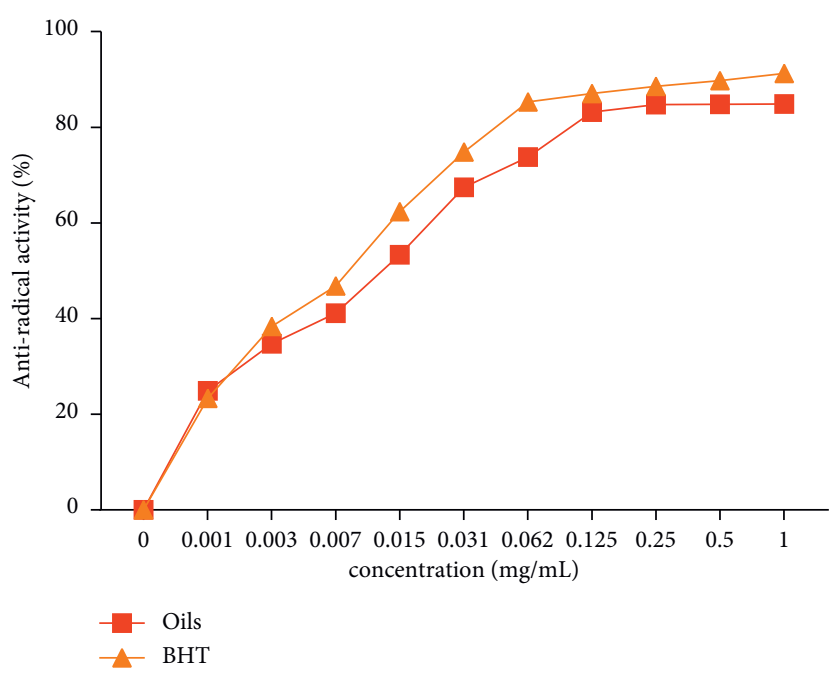

FIgURE 2: DPPH radical scavenging activity of A. negrei essential oil.

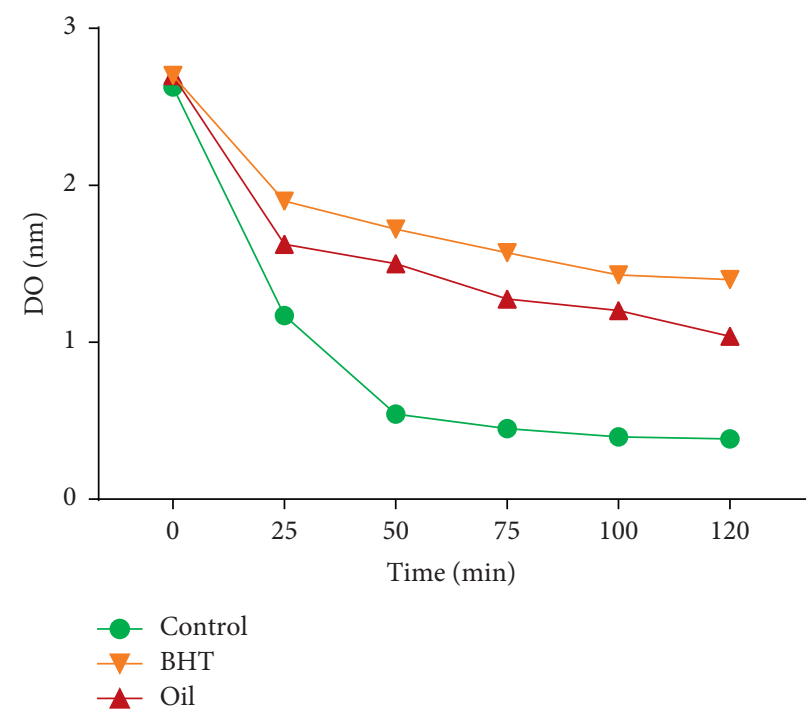

FIgURE 3: Antioxidant activity of $A$. negrei oil by $\beta$-carotene discoloration test.

TABLE 2: Diameter of the zone of inhibition in $\mathrm{mm}$ by the agar diffusion method.

\begin{tabular}{|c|c|c|c|c|c|}
\hline \multirow{2}{*}{ Compound } & \multicolumn{4}{|c|}{ Gram-negative bacteria } & \multirow{2}{*}{$\begin{array}{c}\text { Gram-positive bacteria } \\
\text { S. aureus }\end{array}$} \\
\hline & E. coli 57 & E. coli 97 & K. pneumoniae & $P$. aeruginosa & \\
\hline $\mathrm{EO}$ & $37.21 \pm 1.24$ & $28.37 \pm 3.21$ & $19.05 \pm 2.01$ & $18.51 \pm 0.91$ & $23.41 \pm 2.36$ \\
\hline Streptomycin & - & - & - & - & $9.32 \pm 0.84$ \\
\hline Ampicillin & - & - & - & - & - \\
\hline
\end{tabular}

TABle 3: Minimum inhibitory concentration (MIC in $\mathrm{mg} / \mathrm{mL}$ ).

\begin{tabular}{lccccc}
\hline \multirow{2}{*}{ Compound } & \multicolumn{2}{c}{ Gram-negative bacteria } & \multicolumn{2}{c}{ Gram-positive bacteria } \\
& E. coli 57 & E. coli 97 & K. pneumoniae & P. aeruginosa & S. aureus \\
\hline EO & $6.25 \pm 0.7$ & $6.25 \pm 0.7$ & $6.25 \pm 0.61$ & $1.56 \pm 0.20$ & $12.5 \pm 1.03$ \\
Streptomycin & $4.51 \pm 0.04$ & $5.27 \pm 0.23$ & $3.38 \pm 0.01$ & - & $6.21 \pm 0.04$ \\
Ampicillin & - & - & - & - & - \\
\hline
\end{tabular}




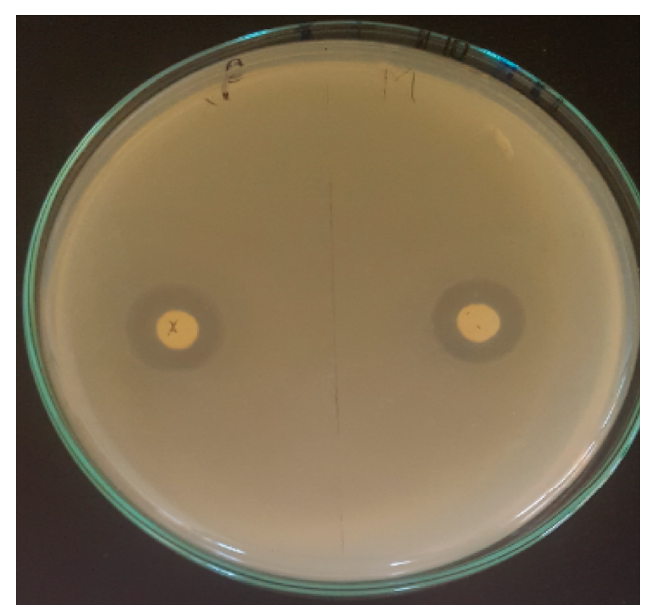

E. coli

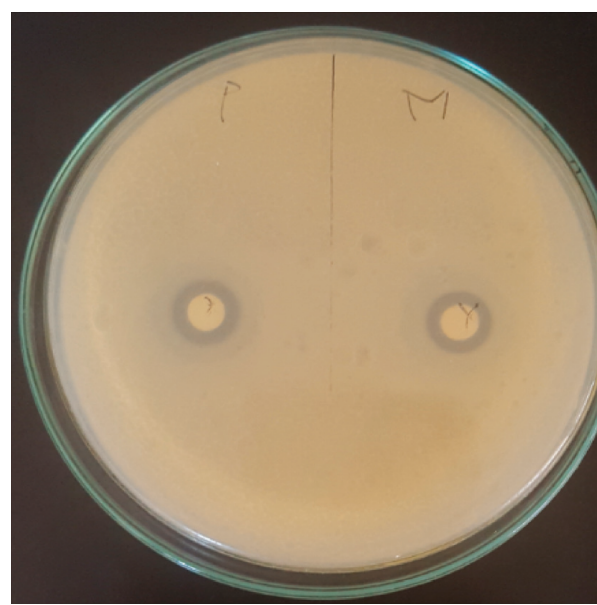

S. aureus

Figure 4: Photograph of Petri dishes showing inhibition zone of essential oils from A.negeri against bacterial strains.

essential oil from $A$. negrei is a potent weapon to fight multidrug-resistant strains.

The obtained findings demonstrated that the bacterial strains tested were found to be resistant to antibiotics ampicillin and streptomycin. These results were in accordance with those investigated in previous literature [43], which revealed that Enterobacter spp., S. aureus, P. aeruginosa, K. pneumoniae, $A$. baumannii along with $E$. coli pathogens were too drugresistant microbes. Moreover, the strains tested in this research work are classified belonging to multidrug-resistant as reported in previous works $[38,40]$.

3.6. Antifungal Activity of Oilfrom A. negrei. Regarding the in vitro evaluation of the antifungal activity of $A$. negrei essential oil, the disk diffusion method revealed antifungal activity with a percentage inhibition of $32.93 \pm 0.53 \%$, $33.80 \pm 1.27 \%$, and $33.66 \pm 0.44$ against $F$. oxysporum, $A$. niger, and C. albicans. However, the essential oils did not show antifungal activity against $A$. flavus when compared to other strains. These results are in agreement with investigated elsewhere [45], which showed that oil from Borojoa patinoi Cuatrec exhibited an inhibitory effect towards C. albicans since both share some common chemicals. Moreover, numerous studies place priority natural products especially essential oil for controlling fungal strains including F. oxysporum, A. niger, A. flavus, and C. albicans [26]. Several epidemiological studies have been conducted on yeast infections indicated that Candida is responsible for many diseases [46]. Thus, the use of alternative treatment from a natural source can serve society to control fungal diseases at low cost.

Previously reported literature on the mechanism of action of essential oil towards fungi showed that essential oils are higher in thymol, and p-cymene penetrates cells inducing membrane damage $[47,48]$. The reported activities in this work were consistent with the chemical composition of monoterpenes, which are the most potentially responsible for cell membrane damage. In previous works, it was reported that the fungicidal effect of thymol and p-cymene oil on Candida spp., resulting in indirect damage to the cytoplasmic membrane of target bacteria [49].

\section{Conclusion}

The present work aimed to shed light on the chemical composition and antioxidant, antibacterial, and antifungal activities of essential oil from $A$. negrei growing in the folded Middle Atlas, Morocco. The results obtained showed that the oil recovered from the studied plant was rich in potentially active compounds. The oil had potent antioxidant, antibacterial, and antifungal activities. Therefore, the oil from A. negrei can be used as a valuable natural source for further research that may lead to developing a new weapon to fight free radical damage and microbial resistance.

\section{Data Availability}

Data used to support the findings are included within the article.

\section{Conflicts of Interest}

The authors declare that they have no conflicts of interest.

\section{Acknowledgments}

The authors extend their appreciation to the Deanship of Scientific Research at King Saud University for funding this work through research group no. (RG-1441-360).

\section{References}

[1] E. Salmerón-Manzano, J. A. Garrido-Cardenas, and F. Manzano-Agugliaro, "Worldwide research trends on medicinal plants," International Journal of Environmental Research and Public Health, vol. 17, no. 10, p. 3376, 2020.

[2] A. El Moussaoui, F. Z. Jawhari, M. Bourhia et al., "Withania Frutescens: Chemical Characterization, Analgesic, Anti-inflammatory, and Healing Activities," Open Chemistry, vol. 18, 2020. 
[3] E. L. M. Abdelfattah, F. Z. Jawhari, E. L. O. khadija, and B. Dalila, "Bari Amina Valorization of the Pharmacological Potential of Phytochemical Compounds Contained in the Crude Extract of the Root of a Plant of Withania Frutescens L," Phytotherapie, vol. 19, no. 2, 2019.

[4] A. Arceusz, I. Radecka, and M. Wesolowski, "Identification of diversity in elements content in medicinal plants belonging to different plant families," Food Chemistry, vol. 120, no. 1, pp. 52-58, 2010.

[5] S. B. Sharma and R. Gupta, "Drug development from natural resource: a systematic approach," Mini Reviews in Medicinal Chemistry, vol. 15, no. 1, pp. 52-57, 2015.

[6] M. Lis-Balchin and S. G. Deans, "Bioactivity of selected plant essential oils against Listeria monocytogenes," Journal of Applied Microbiology, vol. 82, pp. 759-762, 1997.

[7] İ. Kivrak, M. E. Duru, M. Öztürk, N. Mercan, M. Harmandar, and G. Topçu, "Antioxidant, anticholinesterase and antimicrobial constituents from the essential oil and ethanol extract of salvia potentillifolia," Food Chemistry, vol. 116, no. 2, pp. 470-479, 2009.

[8] B. N. Ames, "Carcinogens and anticarcinogens," Antimutagenesis and Anticarcinogenesis Mechanisms, vol. 39, pp. 7-35, 1986.

[9] A. E. Moussaoui, M. Bourhia, F. Z. Jawhari et al., "Withania frutescens. L extract: phytochemical characterization and acute and repeated dose 28-day oral toxicity studies in mice," BioMed Research International, vol. 2020, Article ID 1976298, 7 pages, 2020.

[10] A. EL Moussaoui, M. Bourhia, F. Z. Jawhari et al., "Phytochemical identification, acute, and sub-acute oral toxicity studies of the foliar extract of withania frutescens," Molecules, vol. 25 , no. 19 , p. $4528,2020$.

[11] K. Boumhara, F. Bentiss, M. Tabyaoui et al., "Use of Artemisia mesatlantica essential oil as green corrosion inhibitor for mild steel in $1 \mathrm{M}$ hydrochloric acid solution," International Journal of Electrochemical Sciencehem. Sci.vol. 9, pp. 1187-1206, 2014.

[12] V. Shriram, T. Khare, R. Bhagwat, R. Shukla, and V. Kumar, "Inhibiting bacterial drug efflux pumps via phyto-therapeutics to combat threatening antimicrobial resistance," Frontiers in Microbiology, vol. 9, p. 2990, 2018.

[13] N. Mapara, M. Sharma, V. Shriram, R. Bharadwaj, K. C. Mohite, and V. Kumar, "Antimicrobial potentials of helicteres isora silver nanoparticles against extensively drugresistant (XDR) clinical isolates of Pseudomonas aeruginosa," Applied Microbiology and Biotechnology, vol. 99, no. 24, pp. 10655-10667, 2015.

[14] J. R. Maenza, W. G. Merz, M. J. Romagnoli, J. C. Keruly, R. D. Moore, and J. E. Gallant, "Infection due to fluconazoleresistant Candida in patients with AIDS: prevalence and microbiology," Clinical Infectious Diseases, vol. 24, no. 1, pp. 28-34, 1997.

[15] R. P. Adams, "Identification of Essential Oil Components by Gas Chromatography/Mass Spectrometry," Allured publishing corporation Carol Stream, vol. 456, 2007.

[16] A. EL Moussaoui, M. Bourhia, F. Z. Jawhari et al., "Chemical profiling, antioxidant, and antimicrobial activity against drugresistant microbes of essential oil from withania frutescens $L$," Applied Sciences, vol. 11, no. 11, p. 5168, 2021.

[17] B. Tepe, D. Daferera, A. Sokmen, M. Sokmen, and M. Polissiou, "Antimicrobial and antioxidant activities of the essential oil and various extracts of salvia tomentosa miller (lamiaceae)," Food Chemistry, vol. 90, no. 3, pp. 333-340, 2005.

[18] P. Maskovic, N. Manojlovic, A. Mandic et al., "Phytochemical screening and biological activity of extracts of plant species
Halacsya sendtneri (Boiss.) Dörfl," Chemical Industry, vol. 66, no. 1, pp. 43-51, 2012.

[19] P. R. Dayal B, "Screening of some Indian essential oils for their antifungal properties," Flavour Industries, vol. 2, pp. 484-485, 1971.

[20] A. El Moussaoui, F. Z. Jawhari, A. M. Almehdi et al., "Antibacterial, antifungal and antioxidant activity of total polyphenols of withania frutescens.L," Bioorganic Chem.vol. 93, 2019.

[21] M. S. Mulani, E. E. Kamble, S. N. Kumkar, M. S. Tawre, and K. R. Pardesi, "Emerging strategies to combat ESKAPE pathogens in the era of antimicrobial resistance: a review," Frontiers in Microbiology, vol. 10, p. 539, 2019.

[22] V. M. Thomas, R. M. Brown, D. S. Ashcraft, and G. A. Pankey, "Synergistic effect between nisin and polymyxin B against pandrug-resistant and extensively drug-resistant acinetobacter baumannii," International Journal of Antimicrobial Agents, vol. 53, no. 5, pp. 663-668, 2019.

[23] F. E.-Z. Amrati, M. Bourhia, H. Saghrouchni et al., "Caralluma europaea (guss.) N.E.Br.: anti-inflammatory, antifungal, and antibacterial activities against nosocomial antibiotic-resistant microbes of chemically characterized fractions," Molecules, vol. 26, no. 3, p. 636, 2021.

[24] M. Gulluce, F. Sahin, M. Sokmen et al., "Antimicrobial and antioxidant properties of the essential oils and methanol extract from mentha longifolia L. Ssp. longifolia," Food Chemistry, vol. 103, no. 4, pp. 1449-1456, 2007.

[25] M. Balouiri, M. Sadiki, and S. K. Ibnsouda, "Methods for in vitro evaluating antimicrobial activity: a review," Journal of Pharmaceutical Analysis, vol. 6, no. 2, pp. 71-79, 2016.

[26] A. El Barnossi, F. Moussaid, and A. Iraqi Housseini, "Antifungal activity of Bacillussp. gn-A11-18isolated from decomposing solid green household waste in water and soil against Candida albicans and Aspergillus Niger," EDP Sciences, vol. 150, 2020.

[27] J. Ige-Elegbede, P. Pilkington, S. Gray, and J. Powell, "Barriers and facilitators of physical activity among adults and older adults from black and minority ethnic groups in the UK: a systematic review of qualitative studies," Preventive Medicine Reports, vol. 15, 2019.

[28] H. K. Bencheqroun, M. Ghanmi, B. Satrani, A. Aafi, and A. Chaouch, "Activité antimicrobienne des huiles essentielles d'Artemisia mesatlantica, plante endémique du maroc. Antimicrobial activity of the essential oil of an endemic plant in Morocco," Artemisia Mesatlantica, vol. 81, 2012.

[29] S. Bouhdid, S. N. Skali, M. Idaomar et al., "Antibacterial and antioxidant activities of origanum compactum essential oil," African Journal of Biotechnology, vol. 7, pp. 1563-1570, 2008.

[30] É. Zámboriné Németh, H. Thi Nguyen, and H. Thujone, "Thujone, a widely debated volatile compound: what do we know about it?" Phytochemistry Reviews, vol. 19, no. 2, pp. 405-423, 2020.

[31] S. Kordali, R. Kotan, A. Mavi, A. Cakir, A. Ala, and A. Yildirim, "Determination of the chemical composition and antioxidant activity of the essential oil ofArtemisia dracunculusand of the antifungal and antibacterial activities of TurkishArtemisiaabsinthium,A. dracunculus,Artemisia santonicum, andArtemisia spicigeraEssential oils," Journal of Agricultural and Food Chemistry, vol. 53, no. 24, pp. 94529458, 2005.

[32] A. Kadri, A. Bekir, and D. Mohamed, "Chemical constituents and antioxidant activity of the essential oil from aerial parts of Artemisia herba-alba grown in Tunisian semi-arid region evaluation of milk quality in Tunisian dairy herds view 
project," African Journal of. Biotechnology, vol. 10, pp. 2923-2929, 2011.

[33] S. Siddique, Z. Parveen, S. Firdaus-e-Bareen, and S. Mazhar, "Chemical composition, antibacterial and antioxidant activities of essential oils from leaves of three melaleuca species of Pakistani flora," Arabian Journal of Chemistry, vol. 13, no. 1, pp. $67-74,2020$.

[34] M. Bourhia, F. E. Laasri, K. Aghmih et al., "Phytochemical composition, antioxidant activity, antiproliferative effect and acute toxicity study of bryonia dioica roots used in north african alternative medicine," International Journal of Agriculture and Biology, vol. 23, pp. 597-602, 2020.

[35] M. Bourhia, F. E. Laasri, S. I. Moussa et al., "Phytochemistry, antioxidant activity, antiproliferative effect, and acute toxicity testing of two Moroccan aristolochia species," Evidence-Based Complementary and Alternative Medicine, vol. 2019, Article ID 9710876, 8 pages, 2019.

[36] A. Akrout, L. A. Gonzalez, H. El Jani, and P. C. Madrid, "Antioxidant and antitumor activities of Artemisia campestris and thymelaea hirsuta from southern Tunisia," Food and Chemical Toxicology, vol. 49, no. 2, pp. 342-347, 2011.

[37] H. Mighri, H. Hajlaoui, A. Akrout, H. Najjaa, and M. Neffati, "Antimicrobial and antioxidant activities of Artemisia herbaalba essential oil cultivated in Tunisian arid zone," Comptes Rendus Chimie, vol. 13, no. 3, pp. 380-386, 2010.

[38] D. Lopes-Lutz, D. S. Alviano, C. S. Alviano, and P. P. Kolodziejczyk, "Screening of chemical composition, antimicrobial and antioxidant activities of Artemisia essential oils," Phytochemistry, vol. 69, no. 8, pp. 1732-1738, 2008.

[39] P. Prieto, M. Pineda, and M. Aguilar, "Spectrophotometric quantitation of antioxidant capacity through the formation of a phosphomolybdenum complex: specific application to the determination of vitamin E," Analytical Biochemistry, vol. 269, no. 2, pp. 337-341, 1999.

[40] S. A. Fayed, "Antioxidant and anticancer activities of citrus reticulate (petitgrain Mandarin) and Pelargonium graveolens (Geranium) essential oils," Research Journal of Agriculture and Biological Sciences, vol. 5, pp. 740-747, 2009.

[41] A.-B. Cutillas, A. Carrasco, R. Martinez-Gutierrez, V. Tomas, and J. Tudela, "Thyme essential oils from Spain: aromatic profile ascertained by GC-MS, and their antioxidant, antilipoxygenase and antimicrobial activities," Journal of Food and Drug Analysis, vol. 26, no. 2, pp. 529-544, 2018.

[42] A. Akrout, H. E. Jani, S. Amouri, and M. Neffati, "Screening of antiradical and antibacterial activities of essential oils of Artemisia campestris L., Artemisia herba alba asso, \& thymus capitatus hoff. Et link. Growing wild in the southern of Tunisia," Recent Research in Science and Technology, vol. 2, pp. 29-39, 2010.

[43] Z. Yu, J. Tang, T. Khare, and V. Kumar, "The alarming antimicrobial resistance in ESKAPEE pathogens: can essential oils come to the rescue?" Fitoterapia, vol. 140, p. 104433, 2020.

[44] F. Bakkali, S. Averbeck, D. Averbeck, and M. Idaomar, "Biological effects of essential oils-a review," Food and Chemical Toxicology, vol. 46, no. 2, pp. 446-475, 2008.

[45] C. Chaves-López, D. Usai, M. G. Donadu et al., "Potential of Borojoa patinoiCuatrecasas water extract to inhibit nosocomial antibiotic resistant bacteria and cancer cell proliferationin vitro," Food \& Function, vol. 9, no. 5, pp. 2725-2734, 2018.

[46] M. Develoux and S. Bretagne, "Candidoses et levuroses diverses," EMC-Maladies Infectieuses, vol. 2, no. 3, pp. 119-139, 2005.
[47] L. J. Green, P. Marder, L. L. Mann, L.-C. Chio, and W. L. Current, "LY303366 exhibits rapid and potent fungicidal activity in flow cytometric assays of yeast viability," Antimicrobial Agents and Chemotherapy, vol. 43, no. 4, pp. 830-835, 1999.

[48] C. Pina-Vaz, A. G. Rodrigues, F. Sansonetty, J. Martinez-DeOliveira, A. F. Fonseca, and P.-A. Mårdh, "Antifungal activity of local anesthetics against Candida species," Infectious Diseases in Obstetrics and Gynecology, vol. 8, no. 3-4, pp. 124-137, 2000.

[49] C. Pina-Vaz, F. Sansonetty, A. G. Rodrigues, J. Martinez-DeOliveira, A. F. Fonseca, and P.-A. Mårdh, "Antifungal activity of ibuprofen alone and in combination with fluconazole against Candida species," Journal of Medical Microbiology, vol. 49, no. 9, pp. 831-840, 2000. 